\title{
Factors Associated to Positive Aspects in Caregiving for People Living with Dementia in Family Caregivers
}

\author{
Dian Pratiwi1, Retno Indarwati², Rr. Dian Tristiana ${ }^{2}$ \\ 1 Program Studi Sarjana Keperawatan, Fakultas Keperawatan, Universitas Airlangga \\ 2 Departemen Keperawatan Jiwa, Gerontik \& Komunitas, Fakultas Keperawatan, Universitas Airlangga
}

\section{Article Info}

\section{Article History:}

Submitted: May 19th 2021

Accepted: May 29th 2021

Published: May 31'st, 2021

\section{Keywords:}

Factors; Positive Aspects of Caregiving; Dementia;

Alzheimer's

\begin{abstract}
Caring for People with Dementia (PwD) has various negative effects that are detrimental to caregivers. The existence of Positive Aspects of Caregiving (PAC) makes the experience of caring for PwD more positive, valuable and protects caregivers from various negative impacts while caring for PwD. This study aims to explain the factors associated with PAC. These literature reviews were accessed from six databases (Scopus, CINAHL, Science Direct, ProQuest, PubMed, and SAGE Journal), with the keywords factor, positive aspects of caregiving, Dementia/ Alzheimer's, during January 2021, limited to 2016-2020, and in English. A total of 318 journals were selected using PRISMA, then leaving 16 journals to be analyzed using The Joanna Briggs Institution Checklist. Sixteen journals were analyzed and divided into two themes, factors that affect PAC $(n=9)$ and factors affected by PAC $(n=7)$. Factors that affect PAC are caregiver characteristics, care-recipient characteristics, and social support. Factors affected by PAC are caregiving outcomes. Factors that increase PAC are lower education level, good social support, severe BPSD, shorter duration of care, and relationship with carerecipient (except spouse), and gender (male). The mediating factors that increase PAC are unmet needs and reciprocal filial piety. Factors that lower PAC are higher education level, the use of avoidance coping, and older age. We found inconsistencies in caregiver marital status and relationship with care-recipient because the finding still uncertain.
\end{abstract}

\section{PENDAHULUAN}

Merawat keluarga dengan demensia seringkali dianggap memberatkan [1]. Semakin berat demensia maka kebutuhan pemenuhan aktivitas sehari-hari juga akan semakin besar, belum lagi kondisi lain seperti disorientasi waktu, tempat, orang, serta gangguan perilaku pada Orang dengan Demensia (ODD). Hal inilah yang menjadi tantangan bagi family caregiver [2]. Adanya tantangan tersebut membuat family caregiver seringkali merasakan dampak negatif seperti gangguan psikologis, sosial, dan finansial sebagai dampak merawat lansia demensia di rumah [3].

Berdasarkan data World Alzheimer Report 2015, terdapat 47 juta (ODD) di seluruh dunia. Dari jumlah ini diproyeksikan akan

\footnotetext{
Corresponding author:

Retno Indarwati

retno-i@fkp.unair.ac.id

Media Keperawatan Indonesia, Vol 4 No 2, May 2021

e-ISSN: 2615-1669

ISSN: 2722-2802

DOI: $10.26714 / \mathrm{mki} .4 .2 .2021 .149-163$
} 
meningkat menjadi lebih dari 131 juta pada tahun 2050. Dari total populasi penderita demensia di seluruh dunia, diestimasi terdapat 22,9 juta orang penderita demensia yang ada di Asia [4]. Jumlah orang dengan demensia cenderung meningkat seiring meningkatnya kasus penyakit tidak menular [5]. Kondisi tersebut akan berdampak pada ketergantungan lansia terhadap bantuan orang lain atau Perawatan Jangka Panjang/ Long Term Care.

Positive Aspects of Caregiving (PAC) pada ODD masih termasuk ranah studi baru yang masih terus berkembang dan memiliki definisi istilah yang bervariasi [6]. Kramer mendefinisikan sebagai "penilaian dari peran pengasuhan" [7]. Sedangkan Cohen, Colantonio and Vernich mendefinisikan PAC sebagai "manfaat atau perasaan puas" yang dihasilkan dari pengalaman merawat [8]. Kemudian, Tarlow et al. merangkum beberapa istilah yang sering digunakan dalam mendefinisikan PAC, istilah yang paling sering digunakan adalah "kepuasan" [9].

Berdasarkan beberapa studi sebelumnya, aspek positif perawatan berhubungan dengan dukungan sosial yang baik $[10,11]$, kedekatan dengan ODD, tingkat beban yang lebih tinggi, durasi perawatan yang lebih lama [12,13]. Memahami faktor yang berhubungan dengan aspek positif dari perawatan penting dalam membantu menentukan intervensi yang tepat untuk meningkatkan pengalaman positif, melindungi family caregiver dari dampak negatif dari perawatan [14], meningkatkan kesejahteraan family caregiver, dan kualitas perawatan $[15,16]$.

Adanya beberapa studi yang masih memiliki inkonsistensi, maka peneliti ingin melakukan literature review untuk merangkum beberapa studi dalam lima tahun terakhir mengenai faktor yang berhubungan dengan Posistive Aspects of Caregiving dalam merawat ODD pada family caregiver.

\section{METODE}

Penelitian ini merupakan literature review yang membahas tentang faktor yang berhubungan dengan aspek positif selama merawat Orang dengan Demensia (ODD). Proses seleksi menggunakan PRISMA checklist disesuaikan dengan tujuan dari literature review [17] dan penilaian kualitas menggunakan The Joanna Briggs Institude (JBI) Critical Appraisal. Pencarian artikel dilakukan pada bulan Januari 2021 menggunakan enam database dengan kriteria kualitas tinggi dan sedang, yaitu Scopus, CINAHL, Science Direct, ProQuest, PubMed, dan SAGE Journal. Peneliti menggunakan kata kunci dan boolean operator (AND, OR NOT or AND NOT) yang digunakan untuk memperluas atau menspesifikkan pencarian [17]. Kata kunci dalam literature review ini terdiri dari Factors OR Predictor AND "Positive aspects of caregiving" AND Dementia OR Alzheimer's.

Peneliti menggunakan PICOS framework untuk menemukan artikel sesuai dengan kriteria inklusi dan ekslusi. Kriteria inklusi antara lain artikel yang membahas faktor yang berhubungan dengan PAC pada Demensia atau Alzheimer dan berfokus pada family caregiver/ informal caregiver, membahas intervensi peningkatan PAC, outcomes merupakan faktor yang berhubungan dengan PAC pada family caregiver, desain penelitian cross-sectional study, qualitative study, longitudinal research, mixed method research, artikel yang terbit tahun 2016-2021, dan berbahasa Inggris.

Kriteria eksklusi antara lain artikel yang membahas sesuai topik dengan populasi penelitian formal caregiver, tidak menjelaskan intervensi yang berkaitan dengan PAC, tidak menjelaskan faktor yang berhubungan dengan PAC pada family caregiver, desain penelitian protocol study, meta review, realist review, validation study, randomized controlled trial, systematic review, artikel yang terbit sebelum tahun 2016, selain bahasa Inggris. 


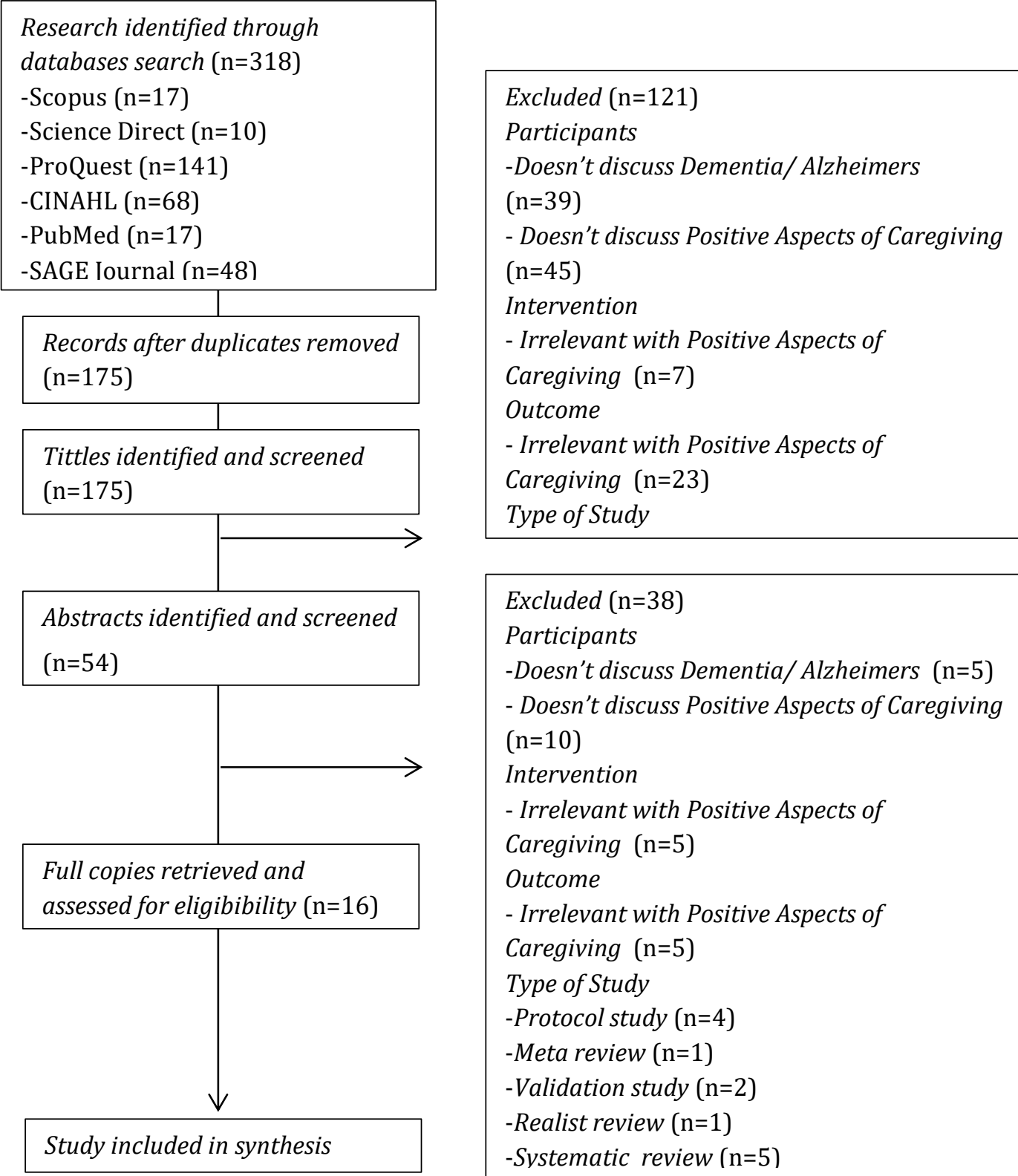

Gambar 1

Diagram Flow Literature Review berdasarkan PRISMA 2009 [18]

\section{HASIL}

Tabel 1

Hasil Pencarian Literatur

\begin{tabular}{|c|c|c|c|c|c|}
\hline No & Author & $\begin{array}{c}\text { Tahun, } \\
\text { Volume, } \\
\text { No }\end{array}$ & Judul & Desain, Sampel & Hasil Penelitian \\
\hline 1. & $\begin{array}{l}\text { Fiona Devi, Qi Yuan, } \\
\text { Peizhi Wang, } \\
\text { Gregory Tee Hng } \\
\text { Tan, Richard Roshan } \\
\text { Goveas, Li Ling Ng, } \\
\text { Siow Ann Chong, } \\
\text { Mythily } \\
\text { Subramaniam }\end{array}$ & $\begin{array}{c}2020 \\
15,8\end{array}$ & $\begin{array}{l}\text { Positive Aspect } \\
\text { of Caregiving } \\
\text { Among Primary } \\
\text { Informal } \\
\text { Dementia } \\
\text { Caregivers in } \\
\text { Singapore }\end{array}$ & $\begin{array}{l}\text { Desain: Cross- } \\
\text { sectional study } \\
\text { Sampel: } 282 \\
\text { informal } \\
\text { caregiver } \\
\text { utama dari ODD }\end{array}$ & $\begin{array}{l}\text { Caregiver Melayu dikaitkan } \\
\text { dengan skor yang lebih tinggi } \\
\text { pada PAC dan 'Afirmasi Diri' } \\
\text { dibandingkan dengan caregiver } \\
\text { dari etnis lain. Caregiver dengan } \\
\text { tingkat pendidikan menengah } \\
\text { atau lebih rendah memiliki PAC } \\
\text { dan skor 'Pandangan Hidup' yang }\end{array}$ \\
\hline
\end{tabular}

Retno Indarwati / Factors Associated to Positive Aspects in Caregiving for People Living with Dementia in Family Caregivers 


\begin{tabular}{|c|c|c|c|c|c|}
\hline No & Author & $\begin{array}{l}\text { Tahun, } \\
\text { Volume, } \\
\text { No }\end{array}$ & Judul & Desain, Sampel & Hasil Penelitian \\
\hline & & & & & $\begin{array}{l}\text { lebih tinggi. Caregiver yang telah } \\
\text { menerima pelatihan formal } \\
\text { mendapat skor lebih tinggi di PAC, } \\
\text { 'Afirmasi Diri' dan 'Pandangan } \\
\text { Hidup'. }\end{array}$ \\
\hline 2. & $\begin{array}{l}\text { Amanda N. Leggett, } \\
\text { Oanh L. Meyer, } \\
\text { Benjamin C. Bugajski, } \\
\text { and Courtney A. } \\
\text { Polenick }\end{array}$ & $\begin{array}{c}2020, \mathrm{I}, \\
9\end{array}$ & $\begin{array}{l}\text { Accentuate the } \\
\text { Positive: The } \\
\text { Association } \\
\text { Between } \\
\text { Informal and } \\
\text { Formal Supports } \\
\text { and Caregiving } \\
\text { Gains }\end{array}$ & $\begin{array}{l}\text { Desain: Cross- } \\
\text { sectional study } \\
\text { Sampel: } 705 \\
\text { caregiver } \\
\text { utama dari ODD }\end{array}$ & $\begin{array}{l}\text { Caregiving gain yang lebih tinggi } \\
\text { secara signifikan terkait dengan } \\
\text { dukungan emosional dari teman } / \\
\text { keluarga }(\beta=0,14, \mathrm{SE}=0,09, \mathrm{p}= \\
0,03) \text { Selain itu, mengikuti } \\
\text { program pelatihan caregiver } \\
\text { hanya dikaitkan dengan } \\
\text { peningkatan caregiver gains di } \\
\text { antara pria }(\beta=0.11, \mathrm{SE}=0.08, \mathrm{p} \\
=.02)\end{array}$ \\
\hline 3. & 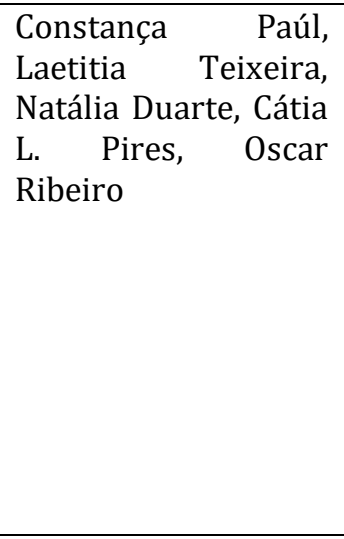 & $\begin{array}{c}2019 \\
55,2\end{array}$ & $\begin{array}{l}\text { Effects of a } \\
\text { Community } \\
\text { Intervention } \\
\text { Program For } \\
\text { Dementia On } \\
\text { Mental Health: } \\
\text { the Importance } \\
\text { of Secondary } \\
\text { Caregivers in } \\
\text { Promoting } \\
\text { Positive Aspects } \\
\text { and Reducing } \\
\text { Strain }\end{array}$ & $\begin{array}{l}\text { Desain: } \text { Cohort } \\
\text { study } \\
\text { Sampel: } 187 \\
\text { caregiver }\end{array}$ & $\begin{array}{l}\text { Faktor yang terkait dengan aspek } \\
\text { positif perawatan adalah usia } \\
\text { caregiver - lebih muda (p = } \\
0,005) \text { dan keberadaan caregiver } \\
\text { sekunder }(p=0,005) \text {. }\end{array}$ \\
\hline 4. & $\begin{array}{l}\text { Catherine Quinn, } \\
\text { Ph.D., Sharon M. } \\
\text { Nelis, Ph.D, Anthony } \\
\text { Martyr, } \\
\text { Christina Ph.D., } \\
\text { Ph.D., Robictor, } \\
\text { Morris, Ph.D., Linda } \\
\text { Clare, Sc.D. }\end{array}$ & $\begin{array}{c}2019 \\
27,8\end{array}$ & $\begin{array}{l}\text { Influence } \\
\text { Positive af } \\
\text { Negative } \\
\text { Dimensions of } \\
\text { Dementia } \\
\text { Caregiving on } \\
\text { Caregiver Well- } \\
\text { Being and } \\
\text { Satisfaction With } \\
\text { Life: Findings } \\
\text { From the IDEAL } \\
\text { Study }\end{array}$ & $\begin{array}{l}\text { Desain: Cross- } \\
\text { sectional study } \\
\text { Sampel: 1,283 } \\
\text { informal } \\
\text { caregiver ODD } \\
\text { dengan tingkat } \\
\text { demensia } \\
\text { ringan hingga } \\
\text { sedang }\end{array}$ & $\begin{array}{l}\text { Kesejahteraan yang lebih rendah } \\
\text { dikaitkan dengan merasakan } \\
\text { aspek positif perawatan yang } \\
\text { lebih sedikit }(-7,67 ; 95 \% \text { CI: - } \\
\text { 10,26, -5,07). Satisfaction with } \\
\text { Life (SwL) yang lebih rendah } \\
\text { dikaitkan dengan merasakan } \\
\text { aspek positif perawatan yang } \\
\text { lebih sedikit (-3.09; 95\% CI: } \\
-3.94,-2.25) \text {. }\end{array}$ \\
\hline 5. & $\begin{array}{l}\text { Noelle L. Fields, PhD, } \\
\text { LCSW and Vivian J. } \\
\text { Miller, LMSW }\end{array}$ & $\begin{array}{c}2019 \\
34,3\end{array}$ & $\begin{array}{l}\text { Caregiver } \\
\text { Burden and } \\
\text { Desire for } \\
\text { Institutional } \\
\text { Placement-The } \\
\text { Roles of Positive } \\
\text { Aspects of } \\
\text { Caregiving and } \\
\text { Religious Coping }\end{array}$ & $\begin{array}{l}\text { Desain: } \text { Cross- } \\
\text { sectional study } \\
\text { Sampel: } 637 \\
\text { caregiver } \\
\text { demensia }\end{array}$ & $\begin{array}{l}\text { Baik Positive Aspects of } \\
\text { Caregiving (PAC) maupun koping } \\
\text { religius terkait secara negatif } \\
\text { dengan Desire to Institutionalize } \\
\text { (DTI); Namun, hanya PAC yang } \\
\text { signifikan. Hanya interaksi antara } \\
\text { gangguan perawatan sehari-hari } \\
\text { dan koping religius yang } \\
\text { signifikan, yang menunjukkan } \\
\text { bahwa efek yang merugikan dari } \\
\text { gangguan perawatan sehari-hari } \\
\text { pada DTI secara signifikan lebih } \\
\text { sedikit pada caregiver yang } \\
\text { memiliki religiusitas. }\end{array}$ \\
\hline 6. & $\begin{array}{l}\text { Maria M. Pert } \\
\text {, Aditi Sooknarine- } \\
\text { Rajpatty, } \quad \text { Sabina }\end{array}$ & $\begin{array}{c}\text { 2019, } \\
\text { 10, July }\end{array}$ & $\begin{array}{l}\text { Caregiver Choice } \\
\text { and Caregiver } \\
\text { Outcomes: A } \\
\text { Longitudinal }\end{array}$ & $\begin{array}{l}\text { Desain: } \\
\text { Longitudinal } \\
\text { study }\end{array}$ & $\begin{array}{l}\text { Caregiver yang melaporkan } \\
\text { caregiver choice yang lebih tinggi } \\
\text { lebih mungkin untuk tetap } \\
\text { memberikan perawatan di rumah }\end{array}$ \\
\hline
\end{tabular}




\begin{tabular}{|c|c|c|c|c|c|}
\hline No & Author & $\begin{array}{l}\text { Tahun, } \\
\text { Volume, } \\
\text { No }\end{array}$ & Judul & Desain, Sampel & Hasil Penelitian \\
\hline & $\begin{array}{l}\text { Brennan, Ian } \\
\text { Robertson and } \\
\text { Brain A. Lawlor }\end{array}$ & & $\begin{array}{l}\text { Study of Irish } \\
\text { Spousal } \\
\text { Dementia } \\
\text { Caregivers }\end{array}$ & $\begin{array}{l}\text { Sampel: } 252 \\
\text { caregiver ODD } \\
\text { (pasangan) }\end{array}$ & $\begin{array}{l}\text { saat follow up dan } \\
\text { mengidentifikasi positive aspects } \\
\text { of caregiving dari memberi } \\
\text { perawatan. Caregiver choice } \\
\text { hanya signifikan berhubungan } \\
\text { dengan persepsi aspek positif } \\
\text { perawatan, beban caregiver, dan } \\
\text { self efficacy. }\end{array}$ \\
\hline 7. & $\begin{array}{l}\text { Ibrahim } \\
\text { Abdollahpour, PhD, } \\
\text { Saharnaz Nedjat, } \\
\text { PhD, and Yahya } \\
\text { Salimi, PhD }\end{array}$ & $\begin{array}{c}2018 \\
31,1\end{array}$ & $\begin{array}{l}\text { Positive Aspects } \\
\text { of Caregiving and } \\
\text { Caregiver } \\
\text { Burden: A Study } \\
\text { of Caregivers of } \\
\text { Patients With } \\
\text { Dementia }\end{array}$ & $\begin{array}{l}\text { Desain: cross- } \\
\text { sectional study } \\
\text { Sampel: } 132 \\
\text { caregiver }\end{array}$ & $\begin{array}{l}\text { Usia caregiver dan status } \\
\text { pernikahan adalah kovariat } \\
\text { tersisa lainnya yang memiliki } \\
\text { hubungan signifikan dengan PAC } \\
\text { dalam model regresi linier. }\end{array}$ \\
\hline 8. & $\begin{array}{l}\text { Haihong Xue, Junwei } \\
\text { Zhai, Runlian He, } \\
\text { Liye Zhou, Ruifeng } \\
\text { Liang, Hongmei Yu }\end{array}$ & $\begin{array}{c}\text { 2018, } \\
\text { 261, } \\
\text { January }\end{array}$ & $\begin{array}{l}\text { Moderating Role } \\
\text { of Positive } \\
\text { Aspects of } \\
\text { Caregiving in the } \\
\text { Relationship } \\
\text { between } \\
\text { Depression in } \\
\text { Persons with } \\
\text { Alzheimer's } \\
\text { Disease and } \\
\text { CaregiverBurden }\end{array}$ & $\begin{array}{l}\text { Desain: cross- } \\
\text { sectional study } \\
\text { Sampel: } 200 \\
\text { pasang pasien } \\
\text { dengan } \\
\text { Demensia } \\
\text { Alzheimer } \\
\text { ringan dan } \\
\text { caregiver } \\
\text { Regression }\end{array}$ & $\begin{array}{l}\text { Efek moderasi yang signifikan } \\
\text { dari PAC ditemukan pada } \\
\text { hubungan antara depresi pada } \\
\text { pasien dengan Demensia } \\
\text { Alzheimer dan beban caregiver } \\
\text { yang ditimbulkannya. Caregiver } \\
\text { yang menangani pasien dengan } \\
\text { tingkat depresi rendah tetapi } \\
\text { dengan tingkat PAC yang tinggi } \\
\text { memiliki tingkat beban caregiver } \\
\text { yang jauh lebih rendah } \\
\text { dibandingkan dengan caregiver } \\
\text { dengan tingkat PAC yang rendah. }\end{array}$ \\
\hline 9. & $\begin{array}{l}\text { Kerry Johanna Smith, } \\
\text { Catriona George, and } \\
\text { Nuno Ferriera }\end{array}$ & $\begin{array}{l}2018 \\
30,11\end{array}$ & $\begin{array}{l}\text { Factors } \\
\text { Emerging from } \\
\text { the "Zarit Burden } \\
\text { Interview" and } \\
\text { Predictive } \\
\text { Variables in a UK } \\
\text { Sample of } \\
\text { Caregivers for } \\
\text { People with } \\
\text { Dementia }\end{array}$ & $\begin{array}{l}\text { Desain: cross- } \\
\text { sectional study } \\
\text { Sampel: } \quad 110 \\
\text { caregiver ODD }\end{array}$ & $\begin{array}{l}\text { Ketidakpastian tentang masa } \\
\text { depan dan frustrasi / rasa malu } \\
\text { diprediksi secara terbalik oleh } \\
\text { PACS, menunjukkan bahwa } \\
\text { memperhatikan aspek positif dari } \\
\text { perawatan dapat berfungsi } \\
\text { sebagai faktor protektif beban } \\
\text { caregiver. }\end{array}$ \\
\hline 10. & $\begin{array}{l}\text { Myonghwa Park, } \\
\text { Sora Choi, Song Ja } \\
\text { Lee, Seon Hwa Kim, } \\
\text { Jinha Kim,Younghye } \\
\text { Go and Dong Young } \\
\text { Lee }\end{array}$ & $\begin{array}{c}2018 \\
30,4\end{array}$ & $\begin{array}{l}\text { The roles of } \\
\text { Unmet Needs } \\
\text { and Formal } \\
\text { Support in the } \\
\text { Caregiving } \\
\text { Satisfaction and } \\
\text { Caregiving } \\
\text { Burden of Family } \\
\text { Caregivers for } \\
\text { Persons with } \\
\text { Dementia }\end{array}$ & $\begin{array}{l}\text { Desain: cross- } \\
\text { sectional study } \\
\text { Sampel: } \quad 320 \\
\text { family } \\
\text { caregiver }\end{array}$ & $\begin{array}{l}\text { Model yang disesuaikan } \\
\text { menjelaskan efek mediasi dari } \\
\text { kebutuhan yang tidak terpenuhi } \\
\text { pada hubungan antara gejala } \\
\text { pasien atau dukungan formal dan } \\
\text { kepuasan dalam merawat. Gejala } \\
\text { pasien dan kepuasan dalam } \\
\text { merawat memiliki pengaruh } \\
\text { langsung yang signifikan terhadap } \\
\text { beban perawatan. }\end{array}$ \\
\hline 11. & $\begin{array}{l}\text { Natalie D. Pope, } \\
\text { Paula K. Baldwin, } \\
\text { Jacquelyn J. Lee }\end{array}$ & $\begin{array}{c}2018 \\
25,3\end{array}$ & $\begin{array}{l}\text { "I Didn't Expect } \\
\text { to Learn as Much } \\
\text { as I Did": } \\
\text { Rewards of } \\
\text { Caregiving in } \\
\text { Young Adulthood }\end{array}$ & $\begin{array}{l}\text { Desain: } \\
\text { qualitative } \\
\text { study } \\
\text { Sampel: } \\
\text { family } \\
\text { caregivers }\end{array}$ & $\begin{array}{l}\text { Empat tema diidentifikasi } \\
\text { berkenaan dengan keuntungan } \\
\text { yang dialami oleh caregiver } \\
\text { dewasa muda: penguatan } \\
\text { hubungan keluarga, pertumbuhan } \\
\text { karakter, kepuasan pribadi dalam } \\
\text { perawatan yang diberikan, dan } \\
\text { keuntungan materi. }\end{array}$ \\
\hline
\end{tabular}




\begin{tabular}{|c|c|c|c|c|c|}
\hline No & Author & $\begin{array}{l}\text { Tahun, } \\
\text { Volume, } \\
\text { No }\end{array}$ & Judul & Desain, Sampel & Hasil Penelitian \\
\hline 12. & $\begin{array}{l}\text { Amy S. Hwang, Lena } \\
\text { Rosenberg, } \\
\text { Kontos, Pill } \\
\text { Cameron, I. } \\
\text { Mihailidis } \\
\text { and Louise Nygård }\end{array}$ & $\begin{array}{c}2017 \\
12 \\
1389578\end{array}$ & $\begin{array}{l}\text { Sustaining Care } \\
\text { for a Parent with } \\
\text { Dementia: an } \\
\text { Indefinite and } \\
\text { Intertwined } \\
\text { Process }\end{array}$ & $\begin{array}{l}\text { Desain: } \\
\text { qualitative } \\
\text { study } \\
\text { Sampel: } \\
\text { partisipan } \\
\text { caregiver } \\
\text { dengan orang } \\
\text { tua demensia }\end{array}$ & $\begin{array}{l}\text { Tema-tema tersebut } \\
\text { menggambarkan bagaimana } \\
\text { kebutuhan perawatan dan } \\
\text { ketergantungan terbentuk pada } \\
\text { caregiver utama (anak), yang } \\
\text { sangat bergantung pada sumber } \\
\text { daya diri mereka sendiri untuk } \\
\text { memenuhi kebutuhan perawatan } \\
\text { segera, ditegaskan dan diperkuat } \\
\text { dalam mempertahankan } \\
\text { komitmen perawatan mereka } \\
\text { dengan aspek positif perawatan. }\end{array}$ \\
\hline 13. & $\begin{array}{lr}\text { Kristin } & \text { Litzelman, } \\
\text { Gina } & \text { Tesauro, } \\
\text { Rebecca } & \text { Ferrer }\end{array}$ & $\begin{array}{l}2017 \\
26,12\end{array}$ & $\begin{array}{l}\text { Internal } \\
\text { Resources } \\
\text { Among Informal } \\
\text { Caregivers: } \\
\text { Trajectories and } \\
\text { Associations } \\
\text { with Well-Being }\end{array}$ & $\begin{array}{l}\text { Desain: cohort } \\
\text { study } \\
\text { Sampel: } \quad 367 \\
\text { caregiver }\end{array}$ & $\begin{array}{l}\text { Caregiver dengan tingkat } \\
\text { personal mastery yang meningkat } \\
\text { atau stabil tinggi memiliki skor } \\
\text { kesejahteraan yang jauh lebih } \\
\text { baik, } 6 \text { dari } 8 \text { pada subskala } \\
\text { dibandingkan dengan tingkat } \\
\text { stabil rendah [ukuran efek (ES) } \\
\text { antara 0,39 dan } 0,79 \text { ]. } \\
\text { Meningkatkan ketekunan } \\
\text { dikaitkan dengan personal growth } \\
\text { yang lebih baik dan penguasaan } \\
\text { lingkungan (ES = 0,96 dan } 0,91 \text { ), } \\
\text { dan positive reappraisal yang } \\
\text { meningkat dan stabil dikaitkan } \\
\text { dengan pengaruh yang lebih baik } \\
\text { (ES=0,63 dan } 0,48 \text { ) dibandingkan } \\
\text { dengan tingkat stabil yang rendah. } \\
\text { Menurunkan aspirasi dan } \\
\text { pencarian dukungan tidak terkait } \\
\text { dengan wellbeing outcomes. }\end{array}$ \\
\hline 14. & $\begin{array}{l}\text { S Grover, R Nehra, R } \\
\text { Malhotra, N Kate }\end{array}$ & $\begin{array}{c}2017 \\
27,2\end{array}$ & $\begin{array}{l}\text { Positive Aspects } \\
\text { of Caregiving } \\
\text { Experience } \\
\text { among } \\
\text { Caregivers of } \\
\text { Patients with } \\
\text { Dementia }\end{array}$ & $\begin{array}{l}\text { Desain: cross- } \\
\text { sectional study } \\
\text { Sampel: } \quad 55 \\
\text { caregiver }\end{array}$ & $\begin{array}{l}\text { Penggunaan yang lebih tinggi dari } \\
\text { avoidance coping berhubungan } \\
\text { dengan pengalaman perawatan } \\
\text { yang positif. Kepuasan caregiver } \\
\text { dikaitkan dengan kualitas hidup } \\
\text { yang lebih baik. }\end{array}$ \\
\hline 15. & $\begin{array}{l}\text { Hua Yu, Li Wu, Shu } \\
\text { Chen, Qing Wu, Yuan } \\
\text { Yang and Helen } \\
\text { Edwards }\end{array}$ & $\begin{array}{l}2016 \\
28,11\end{array}$ & \begin{tabular}{l}
\multicolumn{2}{l}{ Caregiving } \\
Burden and Gain \\
Among Adult- \\
Child Caregivers \\
Caring for \\
Parents with \\
Dementia in \\
China: the Partial \\
Mediating Role of \\
Reciprocal Filial \\
Piety
\end{tabular} & $\begin{array}{l}\text { Desain: cross- } \\
\text { sectional study } \\
\text { Sampel: } \quad 401 \\
\text { caregiver (anak } \\
\text { dewasa) }\end{array}$ & $\begin{array}{l}\text { Nilai absolut dari koefisien regresi } \\
\text { antara BPSD pada ODD dan } \\
\text { caregiver gain berkurang dari c =- } \\
0,75 \text { menjadi c '= }-0,63 \text { saat } \\
\text { mengontrol Reciprocal Filial Piety } \\
\text { (RFP). Estimasi bootstrap dari } \\
\text { efek tidak langsung melalui RFP } \\
\text { antara Behaviour and Psychology } \\
\text { Symptomps of Dementia (BPSD) } \\
\text { pada ODD dan caregiver gain } \\
\text { adalah -0,12 (95\% CI: -0,18, - } \\
0,07) \text {. Proporsi mediasi adalah } \\
12 \% \text {. }\end{array}$ \\
\hline 16. & $\begin{array}{l}\text { Jinmyoung Cho, } \\
\text { Marcia G. Ory and } \\
\text { Alan B. Stevens }\end{array}$ & $\begin{array}{l}2016 \\
20,11\end{array}$ & \begin{tabular}{l}
\multicolumn{2}{l}{ Socioecological } \\
Factors and \\
Positive Aspects \\
of Caregiving: \\
Findings from
\end{tabular} & $\begin{array}{l}\text { Desain: cross- } \\
\text { sectional study } \\
\text { Sampel: } 642 \\
\text { caregivers }\end{array}$ & $\begin{array}{lr}\text { Caregiver Hispanik melaporkan } \\
\text { tingkat PAC tertinggi } & \text { sementara } \\
\text { caregiver } & \text { kulit } \\
\text { menunjukkan skor terendah pada } \\
\text { ukuran PAC. Pendidikan, status } \\
\text { perkawinan, }\end{array}$ \\
\hline
\end{tabular}




\begin{tabular}{|c|c|c|c|c|c|}
\hline No & Author & $\begin{array}{c}\text { Tahun, } \\
\text { Volume, } \\
\text { No }\end{array}$ & Judul & Desain, Sampel & Hasil Penelitian \\
\hline & & & $\begin{array}{l}\text { the REACH II } \\
\text { Intervention }\end{array}$ & & $\begin{array}{l}\text { prediktor signifikan untuk PAC di } \\
\text { antara caregiver Hispanik; usia, } \\
\text { pendidikan, durasi perawatan, } \\
\text { dan dukungan sosial yang } \\
\text { diterima signifikan untuk PAC di } \\
\text { antara caregiver Afrika-Amerika; } \\
\text { dan jenis kelamin, pendidikan, } \\
\text { menjadi caregiver pasangan, } \\
\text { kepuasan dengan dukungan } \\
\text { sosial, dan berpartisipasi dalam } \\
\text { kelompok dukungan adalah } \\
\text { signifikan di antara caregiver kulit } \\
\text { putih. }\end{array}$ \\
\hline
\end{tabular}

Hasil penelitian terbagi menjadi dua tema besar yaitu faktor yang mempengaruhi Positive Aspects of Caregiving (9 studi) dan faktor yang dipengaruhi Positive Aspects of Caregiving (7 studi), yang dapat dilihat pada tabel 2 dan tabel 3.

\section{Etnis}

Informal caregiver dari etnis Melayu memiliki hubungan yang signifikan dan positif dengan PAC. Skor PAC lebih tinggi dibandingkan dengan etnis China, India, dan etnis lain di Singapura $(\beta=2.94,95 \%$ CI [0.20 to 5.68]) [19]. Selain itu, studi lain yang membandingkan PAC di antara tiga etnis di Amerika menunjukkan bahwa caregiver Hispanik memiliki skor PAC yang lebih tinggi dibandingkan dengan caregiver Afrika Amerika, dan caregiver kulit putih. Caregiver Hispanik $(\Delta \mathrm{F}=3.31, \mathrm{p}<.001)$, caregiver Afrika Amerika $(\Delta \mathrm{F}=2.49, \mathrm{p}<$ $.01)$, dan caregiver kulit putih $(\Delta \mathrm{F}=2.35, \mathrm{p}$ $<.05$ ) [20].

\section{Usia}

Studi longitudinal yang dilakukan di Portugal menunjukkan bahwa usia caregiver yang lebih muda berhubungan dengan PAC $(p=0,005)$ [21]. Hal ini didukung oleh studi kualitatif Pope, Baldwin dan Lee dimana caregiver dengan usia lebih muda mendapatkan manfaat antara lain, memperkuat hubungan keluarga (baik antara caregiver dan yang dirawat, ke pasangan, maupun ke saudara), pertumbuhan karakter (spiritual, peningkatan life skill), kepuasan pribadi dalam merawat (merasa bersyukur dapat membantu, menganggap sebagai kesempatan untuk balas budi, merasa sebagai sebuah pencapaian) dan keuntungan materi (tempat tinggal, dukungan finansial) [22]. Selain itu, studi cross sectional oleh Abdollahpour, Nedjat dan Salimi juga mengungkapkan bahwa usia yang lebih tua memiliki skor PAC yang lebih rendah $(\beta=-0,15 ; 95 \%$ CI $[-0,26$ hingga $-0,037] ; P=0,009$ ) [16].

\section{Tingkat pendidikan}

Hasil studi Devi et al., mengungkapkan bahwa informal caregiver dengan tingkat pendidikan sekunder atau yang lebih rendah (dibandingkan dengan sarjana dan di atasnya) memiliki skor PAC yang lebih tinggi ( $\beta=2.41,95 \%$ CI [0.31 to 4.51$]$ ) [19]. Demikian pula, informal caregiver dengan level A atau tingkat pendidikan diploma (dibandingkan dengan sarjana dan di atasnya) memiliki skor PAC yang lebih tinggi ( $\beta=1.04,95 \mathrm{CI}[0.20$ to 1.88$])$. Hal ini sejalan dengan studi Cho, Ory dan Stevens yang membandingkan di antara tiga etnis di Amerika, bahwa caregiver Hispanik dengan tingkat pendidikan lebih tinggi memiliki skor PAC yang lebih rendah $(\beta=-.37, \mathrm{p}<$ $.001)$, pada caregiver Afrika Amerika $(\beta=-$ $.19, \mathrm{p}<.05)$ dan caregiver kulit putih $(\beta=-$ $.22, \mathrm{p}<.01$ ) yang memiliki tingkat 
pendidikan lebih rendah mereka memiliki skor PAC yang lebih tinggi [20].

\section{Status pernikahan}

Caregiver yang belum menikah $(\beta=-4,67$, 95\% CI [-8,12 hingga $-1,21] ; \mathrm{P}=0,009)$ memiliki skor PAC lebih rendah[16]. Hal ini bertentangan dengan studi lainnya yang melaporkan bahwa caregiver Hispanik yang sudah menikah memiliki skor PAC yang lebih rendah $(\beta=-.15, \mathrm{p}<.10)[20]$.

\section{Jenis kelamin}

Jenis kelamin dalam satu studi disebutkan berhubungan dengan PAC. Studi Cho, Ory dan Stevens melaporkan bahwa caregiver laki-laki dengan tingkat pendidikan lebih rendah yang memiliki hubungan sebagai anak atau caregiver dengan hubungan selainnya melaporkan tingkat PAC yang lebih tinggi daripada caregiver perempuan dan caregiver yang memiliki hubungan sebagai pasangan dengan tingkat pendidikan yang lebih tinggi $(\beta=-.15, \mathrm{p}<$ .05) [20].

\section{Durasi perawatan}

Cho, Ory dan Stevens dalam studinya melaporkan bahwa caregiver AmerikaAfrika yang lebih tua dengan tingkat pendidikan yang lebih rendah dan durasi perawatan yang lebih pendek melaporkan tingkat PAC yang lebih tinggi daripada caregiver yang lebih muda, dengan tingkat pendidikan yang lebih tinggi, dan caregiver yang merawat ODD dengan durasi yang lebih lama. $(\beta=-.12, p<.10)[20]$.

\section{Hubungan dengan ODD}

Terdapat dua studi yang membahas hubungan caregiver dengan ODD berkaitan dengan PAC. Studi Cho, Ory dan Stevens menyebutkan bahwa caregiver laki-laki dengan tingkat pendidikan lebih rendah yang memiliki hubungan sebagai anak atau hubungan selainnya melaporkan tingkat PAC yang lebih tinggi daripada caregiver perempuan dan caregiver yang memiliki hubungan sebagai pasangan dengan tingkat pendidikan lebih tinggi $(\beta=-.43, p<.10$ untuk pasangan) [20]. Tidak ada hubungan antara PAC dan hubungan informal caregiver dengan ODD [19].

\section{Tingkat keparahan gejala pada pasien}

Reciprocal Filial Piety pada caregiver anak dewasa secara signifikan berkorelasi positif dengan PAC ( $r=0,38 ; p<0,01)$. Tingkat BPSD yang lebih tinggi secara signifikan dikaitkan dengan beban caregiver yang lebih tinggi ( $c=1,01, \mathrm{p}<0,001)$ dan lebih sedikit PAC ( $c=-0,75, p<0,001)$ seperti yang diharapkan. Lebih banyak RFP secara signifikan dikaitkan dengan lebih sedikit beban $(b=-0,41, p<0,001)$ dan lebih banyak PAC ( $b=0,47, p<0,001)$, mengendalikan kovariat dan BPSD [23]. Selain itu, gejala pasien memiliki pengaruh tidak langsung terhadap PAC dengan kebutuhan yang tidak terpenuhi sebagai mediator [24].

\section{Penggunaan koping menghindar (avoidance coping)}

Studi Grover et al., menunjukkan bahwa caregiver yang lebih banyak menggunakan avoidance coping memiliki skor PACE total yang lebih rendah $(r=-0.276, p=0.04)$, dibandingkan dengan caregiver yang menggunakan strategi koping lainnya (problem focused, seek social support, coercion, collusion) [25].

\section{Dukungan informal}

Caregiver yang lebih banyak membantu pemenuhan ADL $(B=0.03, \beta=0.12, \mathrm{SE}=$ $0.01, p=.04$ ) dan mempunyai teman-teman serta keluarga untuk berbagi cerita $(B=$ $0.20, \beta=0.14, \mathrm{SE}=0.09, \mathrm{p}=.03$ ) memiliki skor PAC yang lebih tinggi [10]. Selain itu, studi Cho, Ory and Stevens tentang perbedaan PAC di antara tiga etnis di Amerika, juga melaporkan bahwa kepuasan dengan dukungan sosial adalah prediktor yang signifikan untuk PAC di antara caregiver kulit putih $(\beta=.30, p<.01)$ [20]. Sedikit berbeda dengan etnis kulit putih, faktor yang berhubungan dengan skor PAC 
yang lebih tinggi pada caregiver AfrikaAmerika adalah lebih sering menerima dukungan sosial $(\beta=.20, p<.05)$. Selain itu, studi Grover et al., menunjukkan bahwa dukungan sosial yang lebih kuat dikaitkan dengan PACE yang lebih tinggi dalam motivasi untuk peran pengasuhan [25].

\section{Dukungan formal}

Studi Devi et al., di Singapura terhadap 282 caregiver utama ODD melaporkan bahwa 68 caregiver yang mengikuti pelatihan formal memiliki skor PAC yang lebih tinggi $(\beta=$ $2,57,95 \%$ CI $[0,65$ hingga 4,49]) [19]. Studi lain oleh Paúl et al., di Portugal, sebanyak 187 pengasuh menyelesaikan program psikoedukasi 10 minggu dan dinilai pada awal, pasca intervensi dan pada tindak lanjut 6 bulan, menunjukkan adanya peningkatan PAC. Hasil studi Legget et al., juga menunjukkan skor PAC yang lebih tinggi pada caregiver yang mengikuti program pelatihan caregiver, namun hasil ini signifikan hanya pada caregiver laki-laki $(\mathrm{B}=0.19, \beta=0.11, \mathrm{SE}=0.08, \mathrm{p}=.02)$ [10]. Pada hasil terlihat bahwa terdapat peningkatan skor PAC sebanyak 0.19 (dengan rentang skala $=0-2$ ) [21] .

Tabel 2

Faktor yang Mempengaruhi Positive Aspects of Caregiving

\begin{tabular}{|c|c|c|c|}
\hline Sumber empiris utama & $\begin{array}{c}\text { Faktor yang mempengaruhi Positive Aspects } \\
\text { of Caregiving }\end{array}$ & Keterangan & Tema \\
\hline Devi et al., 2020 [19] & $\begin{array}{l}\text { Etnis Malaysia, tingkat pendidikan yang lebih } \\
\text { rendah } \\
\text { Mengikuti pelatihan formal }\end{array}$ & PAC lebih tinggi & $\begin{array}{l}\text { Karakteristik } \\
\text { caregiver } \\
\text { Dukungan sosial }\end{array}$ \\
\hline Leggett et al., 2020 [10] & Mengikuti pelatihan formal, dukungan sosial & PAC lebih tinggi & Dukungan sosial \\
\hline Paúl et al., 2019 [21] & $\begin{array}{l}\text { Usia caregiver yang lebih muda, adanya } \\
\text { caregiver sekunder }\end{array}$ & PAC lebih tinggi & $\begin{array}{l}\text { Karakteristik } \\
\text { caregiver }\end{array}$ \\
\hline Pertl et al., 2019 [26] & Pilihan caregiver (caregiver choice) & PAC lebih tinggi & $\begin{array}{l}\text { Karakteristik } \\
\text { caregiver }\end{array}$ \\
\hline $\begin{array}{l}\text { Abdollahpour, Nedjat } \\
\text { and Salimi, } 2018 \text { [16] }\end{array}$ & $\begin{array}{l}\text { Usia yang lebih tua, status pernikahan (belum } \\
\text { menikah) }\end{array}$ & PAC lebih rendah & $\begin{array}{l}\text { Karakteristik } \\
\text { caregiver }\end{array}$ \\
\hline $\begin{array}{l}\text { Pope, Baldwin and Lee, } \\
2018 \text { [22] }\end{array}$ & Usia caregiver yang lebih muda & PAC lebih tinggi & $\begin{array}{l}\text { Karakteristik } \\
\text { caregiver }\end{array}$ \\
\hline Park et al., 2018 [24] & $\begin{array}{l}\text { Tingkat keparahan gejala demensia pada } \\
\text { pasien } \\
\text { Dukungan formal (unmet need as a mediator) }\end{array}$ & PAC lebih tinggi & $\begin{array}{l}\text { Karakteristik } \\
\text { ODD } \\
\text { Dukungan sosial }\end{array}$ \\
\hline Grover et al., 2017 [25] & $\begin{array}{l}\text { Penggunaan koping menghindar (avoidance } \\
\text { coping), beban caregiver yang lebih tinggi } \\
\text { Dukungan sosial }\end{array}$ & $\begin{array}{l}\text { PAC lebih rendah } \\
\text { PAC lebih tinggi }\end{array}$ & $\begin{array}{l}\text { Karakteristik } \\
\text { caregiver } \\
\text { Dukungan sosial }\end{array}$ \\
\hline \multirow[t]{5}{*}{$\begin{array}{l}\text { Cho, Ory and Stevens, } \\
2016 \text { [20] }\end{array}$} & Etnis Hispanik & PAC lebih tinggi & $\begin{array}{l}\text { Karakteristik } \\
\text { caregiver }\end{array}$ \\
\hline & $\begin{array}{l}\text { Etnis hispanik dengan tingkat pendidikan } \\
\text { yang lebih tinggi, status pernikahan (sudah } \\
\text { menikah), }\end{array}$ & PAC lebih rendah & $\begin{array}{l}\text { Karakteristik } \\
\text { caregiver }\end{array}$ \\
\hline & $\begin{array}{l}\text { Etnis Afrika Amerika dengan usia lebih tua, } \\
\text { tingkat pendidikan lebih rendah, durasi } \\
\text { perawatan lebih pendek }\end{array}$ & PAC lebih tinggi & $\begin{array}{l}\text { Karakteristik } \\
\text { caregiver }\end{array}$ \\
\hline & Lebih sering menerima dukungan & & Dukungan sosial \\
\hline & $\begin{array}{l}\text { Etnis kulit putih yang memiliki hubungan } \\
\text { dengan ODD selain sebagai pasangan, jenis } \\
\text { kelamin laki-laki, kepuasan dengan dukungan } \\
\text { sosial, tingkat pendidikan lebih rendah, } \\
\text { berpartisipasi dalam kelompok dukungan }\end{array}$ & PAC lebih tinggi & \\
\hline Yu et al., 2016 [23] & $\begin{array}{l}\text { BPSD pada ODD } \rightarrow \text { PAC (Reciprocal Filial Piety } \\
\text { as moderator) }\end{array}$ & PAC lebih tinggi & $\begin{array}{l}\text { Karakteristik } \\
\text { ODD }\end{array}$ \\
\hline
\end{tabular}

Retno Indarwati / Factors Associated to Positive Aspects in Caregiving for People Living with Dementia in Family Caregivers 


\section{Kesejahteraan caregiver}

Kesejahteraan caregiver yang lebih rendah dikaitkan dengan merasakan aspek positif perawatan yang lebih sedikit $(-7,67 ; 95 \%$ CI: -10,26, -5,07) [27]. Peningkatan positive reappraisal dikaitkan dengan 5 subskala kesejahteraan (otonomi, pertumbuhan pribadi, penguasaan lingkungan, pengaruh, dan kepuasan hidup : ES (Effect Size) rentang dari 0.32 hingga 0.44) [28].

\section{Kepuasan dengan hidup}

SwL yang lebih rendah dikaitkan dengan merasakan aspek positif perawatan yang lebih sedikit (-3.09; 95\% CI: $-3.94,-2.25)$ [27].

\section{Keputusan untuk menempatkan ODD ke institusi}

PAC merupakan faktor signifikan dari DTI (Desire to Institutionalize) $(\beta=-.29, \mathrm{P}$ $<.001)$. Hal ini menunjukkan bahwa caregiver yang mengalami PAC secara signifikan lebih kecil kemungkinannya untuk menempatkan ODD ke institusi perawatan jangka panjang [29].

\section{Beban caregiver}

Studi Xue et al., melaporkan bahwa efek moderasi yang signifikan dari PAC ditemukan pada hubungan antara depresi pada pasien dengan Demensia Alzheimer dan beban caregiver yang ditimbulkannya [30]. Caregiver yang menangani pasien dengan tingkat depresi rendah tetapi dengan tingkat PAC yang tinggi memiliki tingkat beban caregiver yang jauh lebih rendah dibandingkan dengan caregiver dengan tingkat PAC yang rendah. Selain itu, studi lain oleh Park et al., menunjukkan adanya efek mediasi dari kebutuhan yang tidak terpenuhi (unmet need) pada hubungan antara gejala pasien/ BPSD atau dukungan formal dan PAC [24]. Menurut Smith, George dan Ferreira ketidakpastian tentang masa depan dan frustrasi / rasa malu diprediksi secara terbalik oleh PACS, menunjukkan bahwa memperhatikan PAC dapat berfungsi sebagai faktor protektif beban caregiver [31]. Studi Abdollahpour, Nedjat dan Salimi melaporkan bahwa beban caregiver berhubungan negatif dengan PAC [16].

\section{Perawatan yang berkelanjutan}

Studi Hwang et al., melaporkan bahwa tema-tema dalam hasil studinya menggambarkan bagaimana kebutuhan perawatan dan ketergantungan terbentuk pada caregiver utama (anak), yang sangat bergantung pada sumber daya diri mereka sendiri untuk memenuhi kebutuhan perawatan segera, ditegaskan dan diperkuat dalam mempertahankan komitmen perawatan mereka dengan aspek positif perawatan [32].

\section{Kualitas hidup caregiver}

Grover et al., dalam studinya melaporkan bahwa kepuasan caregiver dikaitkan dengan kualitas hidup yang lebih baik [25].

Tabel 3

Faktor yang Dipengaruhi Positive Aspects of Caregiving

\begin{tabular}{|c|c|c|c|}
\hline Sumber empiris utama & $\begin{array}{c}\text { Faktor yang dipengaruhi Positive } \\
\text { Aspects of Caregiving }\end{array}$ & Keterangan & Tema \\
\hline Quinn et al., 2019 [27] & $\begin{array}{l}\text { Kesejahteraan caregiver dan kepuasan } \\
\text { dengan hidup }\end{array}$ & Meningkatkan & \multirow{4}{*}{ Caregiving Outcomes } \\
\hline $\begin{array}{l}\text { Fields, } \mathrm{Xu} \text { and Miller, } 2019 \\
\text { [29] }\end{array}$ & $\begin{array}{l}\text { Keputusan untuk menempatkan ODD } \\
\text { ke institusi }\end{array}$ & Mengurangi & \\
\hline Xue et al., $2018[30]$ & $\begin{array}{l}\text { Depresi pada caregiver } \rightarrow \text { Beban } \\
\text { caregiver (PAC as moderating effect) }\end{array}$ & $\begin{array}{l}\text { Mengurangi } \\
\text { beban }\end{array}$ & \\
\hline Park et al., 2018 [24] & $\begin{array}{l}\text { Kebutuhan yang tidak terpenuhi } \rightarrow \\
\text { Beban caregiver (caregiver satisfaction } \\
\text { as mediator) }\end{array}$ & $\begin{array}{l}\text { Mengurangi } \\
\text { beban }\end{array}$ & \\
\hline
\end{tabular}

Retno Indarwati / Factors Associated to Positive Aspects in Caregiving for People Living with Dementia in Family Caregivers 


\begin{tabular}{|c|c|c|c|}
\hline Sumber empiris utama & $\begin{array}{c}\text { Faktor yang dipengaruhi Positive } \\
\text { Aspects of Caregiving }\end{array}$ & Keterangan & Tema \\
\hline $\begin{array}{l}\text { Smith, George and Ferreira, } \\
2018 \text { [31] }\end{array}$ & Beban caregiver & Mengurangi & \\
\hline Grover et al., 2017 [25] & Kualitas hidup caregiver & Meningkatkan & \\
\hline $\begin{array}{l}\text { Litzelman, Tesauro and } \\
\text { Ferrer, 2017 [28] }\end{array}$ & Kesejahteraan caregiver & Meningkatkan & \\
\hline Hwang et al., 2017 [32] & Perawatan yang berkelanjutan & Meningkatkan & \\
\hline
\end{tabular}

\section{PEMBAHASAN}

\section{Faktor yang Mempengaruhi Aspek Positif dalam Perawatan (Positive Aspects of Caregiving)}

\section{Karakteristik Caregiver}

Berdasarkan analisis peneliti, karakteristik caregiver yang mempengaruhi positive aspects of caregiving pada family caregiver yang merawat ODD antara lain: etnis, usia, tingkat pendidikan, status pernikahan, jenis kelamin, durasi perawatan, hubungan caregiver dengan ODD, dan penggunaan avoidance coping.

Perbedaan etnis/ ras dan budaya menunjukkan keragaman sumber daya caregiver, penggunaan strategi koping, serta tingkat stressor, hal tersebut seringkali mempengaruhi pengalaman caregiver dan peran mereka dalam merawat ODD [19]. Menurut studi Pope, Baldwin and Lee dan Paúl et al., caregiver dengan usia yang lebih muda memiliki skor PAC lebih tinggi serta mengalami beberapa hal positif selama merawat ODD, antara lain penguatan hubungan keluarga, pengembangan karakter, kepuasan pribadi dalam perawatan yang diberikan, dan manfaat materi, jika dibandingkan dengan caregiver yang lebih tua $[21,19]$.

Caregiver dengan tingkat pendidikan yang lebih rendah dalam memiliki skor PAC yang lebih tinggi dibandingkan caregiver yang memiliki tingkat pendidikan lebih tinggi karena cara pandang dan ekspektasi hidup yang lebih sederhana $[24,18]$. Mereka yang memiliki tingkat pendidikan lebih tinggi lebih mengutamakan tujuan karier atau mengejar nilai-nilai lain untuk mendapatkan prestasi yang lebih positif daripada menjalankan tanggung jawab untuk merawat ODD [20].

Studi Abdollahpour, Nedjat and Salimi melaporkan bahwa caregiver yang belum menikah memiliki skor PAC lebih rendah dibandingkan dengan caregiver yang sudah menikah [16]. Bagi caregiver yang sudah menikah, proses merawat ini dapat memberikan efek yang positif terhadap hubungan caregiver dengan pasangannya, sebagaimana dalam studi [32] ikatan dengan pasangan juga dibina melalui berbagi hal-hal menyenangkan dan tantangan sehari-hari dalam merawat ODD. Sebaliknya, dalam studi cross-sectional Cho, Ory and Stevens dilaporkan bahwa caregiver Hispanik yang sudah menikah memiliki skor PAC yang lebih rendah, namun hal ini belum dapat dijelaskan penyebabnya [20].

Jenis kelamin laki-laki memiliki skor PAC yang lebih tinggi dibandingkan dengan perempuan [20]. Dalam literatur lain disebutkan bahwa perempuan dinyatakan memiliki skor yang lebih rendah $[24,25]$. Mereka umumnya mengalami ketegangan peran yang lebih besar karena perempuan lebih intens dalam memberikan perawatan, sehingga lebih sering mengalami masalah kesehatan, memiliki pandangan hidup yang kurang positif, dan membutuhkan dukungan eksternal lebih besar [34,35].

Durasi perawatan juga termasuk salah satu faktor yang mempengaruhi PAC, di dalam studi [20] disebutkan bahwa caregiver etnis Afrika-Amerika yang memiliki durasi perawatan lebih pendek memiliki skor PAC 
yang lebih tinggi dibandingkan dengan caregiver yang memiliki durasi perawatan yang lebih panjang. Semakin gejala memburuk, maka dapat mengakibatkan peningkatan stres emosional dan depresi bagi caregiver [37].

Hubungan ODD dengan caregiver (selain sebagai pasangan) memiliki skor PAC yang lebih tinggi dibandingkan dengan caregiver yang memiliki hubungan sebagai anak atau yang lainnya [20]. Caregiver sebagai pasangan melaporkan lebih banyak gejala depresi, beban keuangan dan fisik yang lebih besar, serta tingkat kesejahteraan psikologis yang lebih rendah. Tingkat tekanan psikologis yang lebih tinggi di antara pasangan sebagian besar dikarenakan oleh kebutuhan perawatan yang lebih tinggi [38]. Berlawanan dengan studi sebelumnya, studi Devi et al., melaporkan bahwa tidak ada hubungan antara PAC dan hubungan caregiver dengan ODD [19].

Penggunaan avoidance coping yang lebih tinggi pada caregiver berhubungan dengan rendahnya skor (Positive Aspects of Caregiving Experience) PACE dibandingkan dengan caregiver yang menggunakan strategi koping lainnya (problem focused, seek social support, coercion, collusion) [25]. Ketergantungan pada avoidance coping sangat mungkin menimbulkan berbagai pemicu stres baru, seperti masalah keuangan atau kesehatan, memperburuk ketegangan dalam keluarga atau hubungan kerja ketika terjadi pelepasan emosi, karena hanya menghindari, bukan menyelesaikan masalah [39].

\section{Karakteristik ODD}

Orang tua yang memiliki Behavior and Psychological Symptoms of Dementia (BPSD) lebih parah akan cenderung membuat caregiver (anak) menjadi kurang memiliki motivasi untuk memberikan perawatan dan kurang berbakti, namun ketika memiliki tingkat Reciprocal Filial Piety (RFP) yang lebih tinggi caregiver akan dapat menilai perawatan dengan lebih positif [23]. Gejala pasien memiliki efek tidak langsung pada PAC dengan kebutuhan yang tidak terpenuhi (unmet need) sebagai mediator. Pasien demensia yang memiliki gejala lebih banyak. juga memiliki jumlah kebutuhan yang belum terpenuhi secara signifikan lebih tinggi [24]. Peningkatan keparahan gejala pasien dapat memberikan perasaan "tumbuh" bagi caregiver karena adanya pengembangan keterampilan dan kompetensi baru sebagai caregiver [40]. Caregiver yang lebih sering memenuhi kebutuhan ADL memiliki skor PAC yang lebih tinggi, karena lebih memungkinkan mendapatkan pengalaman yang lebih kaya karena berfokus pada keuntungan yang mereka alami [10].

\section{Dukungan Sosial}

Dukungan sosial dapat berupa dukungan dari teman maupun keluarga untuk saling berbagi [10]. Adanya dukungan sosial yang lebih kuat dikaitkan dengan positive aspects of caregiving experience (PACE) yang lebih tinggi dalam motivasi untuk peran pengasuhan [25]. Selain itu, adanya caregiver sekunder juga membantu meningkatkan PAC [21]. Anggota keluarga lain, teman atau tetangga dapat membantu merawat ODD, baik dengan bergantian merawat dengan caregiver, membantu kegiatan instrumental lainnya, atau sekadar dengan memberikan dukungan emosional. Caregiver yang telah mengikuti pelatihan formal dikaitkan dengan PAC yang lebih tinggi jika dibandingkan dengan caregiver yang tidak mengikuti $[18,10]$. Adanya program psikoedukasi pada komunitas menunjukkan peningkatan kesehatan mental, peningkatan PAC, dan mengurangi ketegangan dalam merawat ODD[21].

\section{Faktor yang Dipengaruhi oleh Aspek Positif dalam Perawatan (Positive Aspects of Caregiving)}

\section{Caregiving Outcomes}

Studi Quinn et al., melaporkan bahwa kesejahteraan caregiver dan kepuasan 
hidup memiliki hubungan negatif dengan positive aspects of caregiving [27]. PAC dapat mengurangi beberapa efek negatif pengasuhan, karena beberapa studi melaporkan bahwa PAC dikaitkan dengan tingkat beban dan depresi yang lebih rendah dan kesehatan mental yang lebih baik secara keseluruhan [41]. Positive aspects of caregiving juga bertindak sebagai mediator untuk memperbaiki stres dalam pengasuhan untuk mempertahankan kualitas hidup caregiver [9].

PAC berfungsi melindungi dan menurunkan depresi pada ODD dan memberikan fungsi protektif terhadap beban caregiver serta menjadi mediator pada hubungan antara depresi pada ODD dan beban caregiver yang dihasilkan [28,29]. Gejala pasien berhubungan positif dengan kepuasan dalam merawat ODD serta beban perawatan, tingkat keparahan gejala pasien menjadikan tingkat kepuasan pengasuhan dan beban pengasuhan yang lebih tinggi [24]. Caregiver yang mengalami PAC, lebih kecil kemungkinannya untuk menempatkan ODD ke institusi perawatan jangka panjang $[27,20]$. PAC dapat membantu caregiver untuk tetap memberikan perawatan secara berkelanjutan [32].

\section{SIMPULAN}

Faktor yang berhubungan dengan positive aspects of caregiving dapat dibagi menjadi dua, yaitu faktor yang mempengaruhi positive aspects of caregiving dan faktor yang dipengaruhi positive aspects of caregiving. Adapun faktor yang mempengaruhi positive aspects of caregiving dapat dikelompokkan menjadi tiga, yaitu karakteristik caregiver (etnis, usia, tingkat pendidikan, status pernikahan, jenis kelamin, durasi perawatan, hubungan caregiver dengan ODD, dan penggunaan avoidance coping), karakteristik ODD (tingkat keparahan gejala pada ODD), dan dukungan sosial (dukungan formal dan dukungan informal). Sedangkan faktor yang dipengaruhi oleh positive aspects of caregiving dikelompokkan menjadi caregiving outcomes (kesejahteraan dan kepuasan hidup, beban caregiver, keputusan untuk menempatkan ODD ke institusi perawatan jangka panjang, dan perawatan yang berkelanjutan).

Faktor yang meningkatkan PAC antara lain etnis (etnis melayu, etnis hispanik), tingkat pendidikan yang lebih rendah, dukungan sosial yang baik, BPSD yang lebih berat pada ODD, durasi perawatan yang lebih pendek, hubungan dengan ODD (selain sebagai pasangan). dan jenis kelamin (laki-laki). Faktor mediator yang dapat meningkatkan PAC yaitu unmet need dan reciprocal filial piety. Faktor yang menurunkan PAC yaitu tingkat pendidikan yang lebih tinggi, penggunaan avoidance coping, dan usia yang lebih tua. Masih terdapat inkonsistensi pada status pernikahan dan hubungan caregiver dengan ODD karena temuan masih samar.

\section{UCAPAN TERIMAKASIH}

Terima kasih kepada Badan PPSDM Kesehatan Kementerian Kesehatan RI dan semua pihak yang telah memberikan dukungan untuk menyelesaikan penelitian ini.

\section{REFERENSI}

[1] Yu DSF, Cheng S-T, Wang J, Building EL. Unravelling positive aspects of caregiving in dementia: An integrative review of research literature. Int J Nurs Stud 2018;79:1-26. https://doi.org/10.1016/j.ijnurstu.2017.10.00 8.

[2] World Health Organization. iSupport For Dementia Training and Support Manual for Carers of People with Dementia. 2019.

[3] Rosyidul M, Lestari R, Magister Keperawatan Fakultas Kedokteran Universitas Brawijaya M, Program Magister Keperawatan Fakultas Kedokteran Universitas Brawijaya P. Studi Fenomenologi Pengalaman Keluarga Sebagai Primary Caregiver Dalam Merawat Lansia Dengan Demensia Di Kabupaten Jombang. Indones J Heal Sci 2015;6:40-51.

[4] Alzheimer's Disease International. World Alzheimer Report. London: 2015.

[5] Kementerian Kesehatan RI. Profil Kesehatan Indonesia 2018 Kemenkes RI. 2019.

Retno Indarwati / Factors Associated to Positive Aspects in Caregiving for People Living with Dementia in Family Caregivers 
[6] Branger C, O'Connell ME, Peacock S. Protocol for a meta-integration: investigating positive aspects of caregiving in dementia. BMJ Open 2018;8:e021215.

https://doi.org/10.1136/bmjopen-2017021215.

[7] Kramer BJ. Gain in the Caregiving Experience: Where Are We? What Next? vol. 37. 1997.

[8] Cohen CA, Colantonio A, Vernich L. Positive aspects of caregiving: rounding out the caregiver experience. Int J Geriatr Psychiatry 2002;17:184-8.

https://doi.org/10.1002/gps.561.

[9] Tarlow BJ, Wisniewski SR, Belle SH, Rubert M, Ory MG, Gallagher-Thompson D. Positive aspects of caregiving: Contributions of the REACH project to the development of new measures for Alzheimer's caregiving. Res Aging 2004;26:429-53.

https://doi.org/10.1177/0164027504264493.

[10] Leggett AN, Meyer OL, Bugajski BC, Polenick CA. Accentuate the Positive: The Association Between Informal and Formal Supports and Caregiving Gains. J Appl Gerontol 2020;I:073346482091448.

https://doi.org/10.1177/0733464820914481.

[11] García-Mochón L, Peña-Longobardo LM, RíoLozano M Del, Oliva-Moreno J, LarrañagaPadilla I, Del Mar García-Calvente M. Determinants of burden and satisfaction in informal caregivers: Two sides of the same coin? the CUIDAR-SE study. Int J Environ Res Public Health 2019;16. https://doi.org/10.3390/ijerph16224378.

[12] Pendergrass A, Mittelman M, Graessel E, Özbe D, Karg N. Predictors of the personal benefits and positive aspects of informal caregiving. Aging Ment Health 2019;23:1533-8. https://doi.org/10.1080/13607863.2018.150 1662.

[13] de Labra C, Millán-Calenti JC, Buján A, NúñezNaveira L, Jensen AM, Peersen MC, et al. Predictors of caregiving satisfaction in informal caregivers of people with dementia. Arch Gerontol Geriatr 2015;60:380-8. https://doi.org/10.1016/j.archger.2015.03.00 2.

[14] de Labra C, Millán-Calenti JC, Buján A, NúñezNaveira L, Jensen AM, Peersen MC, et al. Predictors of caregiving satisfaction in informal caregivers of people with dementia. Arch Gerontol Geriatr 2015;60:380-8. https://doi.org/10.1016/j.archger.2015.03.00 2.

[15] Semiatin AM, O'Connor MK. The relationship between self-efficacy and positive aspects of caregiving in Alzheimer's disease caregivers.
Aging Ment Health 2012;16:683-8. https://doi.org/10.1080/13607863.2011.651 437.

[16] Abdollahpour I, Nedjat S, Salimi Y. Positive Aspects of Caregiving and Caregiver Burden: A Study of Caregivers of Patients With Dementia. J Geriatr Psychiatry Neurol 2018;31:34-8. https://doi.org/10.1177/0891988717743590.

[17] Nursalam, Kusnanto, Eka, Yusuf A, Ninuk, Tintin, et al. Pedoman Penyusunan Skripsi Literature Review-Tesis dan Systematic Review. Surabaya: Fakultas Keperawatan Universitas Airlangga; 2020.

[18] Polit DF, Beck CT. Essentials of Nursing Research: Appraising Evidence for Nursing Practice. China: Lippincott Williams and Wilkins; 2013.

[19] Devi F, Yuan Q, Wang P, Tan GTH, Roshan Goveas R, Ng LL, et al. Positive aspect of caregiving among primary informal dementia caregivers in Singapore. PLoS One 2020;15:e0237677.

https://doi.org/10.1371/journal.pone.023767 7.

[20] Cho J, Ory MG, Stevens AB. Socioecological factors and positive aspects of caregiving: findings from the REACH II intervention. Aging Ment Health 2016;20:1190-201. https://doi.org/10.1080/13607863.2015.106 8739.

[21] Paúl C, Teixeira L, Duarte N, Pires CL, Ribeiro O. Effects of a community intervention program for dementia on mental health: the importance of secondary caregivers in promoting positive aspects and reducing strain. Community Ment Health J 2019;55:296-303. https://doi.org/10.1007/s10597-018-0345-6.

[22] Pope ND, Baldwin PK, Lee JJ. "I Didn't Expect to Learn as Much as I Did": Rewards of Caregiving in Young Adulthood. J Adult Dev 2018;25:18697. https://doi.org/10.1007/s10804-0189284-2.

[23] Yu H, Wu L, Chen S, Wu Q, Yang Y, Edwards H. Caregiving burden and gain among adult-child caregivers caring for parents with dementia in China: the partial mediating role of reciprocal filial piety. Int Psychogeriatrics 2016;28:184555.

https://doi.org/http://dx.doi.org/10.1017/S1 041610216000685.

[24] Park M, Choi S, Lee SJ, Kim SH, Kim J, Go Y, et al. The roles of unmet needs and formal support in the caregiving satisfaction and caregiving burden of family caregivers for persons with dementia. Int Psychogeriatrics 2018;30:55767.

https://doi.org/http://dx.doi.org/10.1017/S1

Retno Indarwati / Factors Associated to Positive Aspects in Caregiving for People Living with Dementia in Family Caregivers 
04161021700196X.

[25] Grover S, Nehra R, Malhotra R, Kate N. Positive Aspects of Caregiving Experience among Caregivers of Patients with Dementia. East Asian Arch Psychiatry 2017;27:71-8.

[26] Pertl MM, Sooknarine-Rajpatty A, Brennan S, Robertson IH, Lawlor BA. Caregiver Choice and Caregiver Outcomes: A Longitudinal Study of Irish Spousal Dementia Caregivers. Front Psychol 2019;10. https://doi.org/10.3389/fpsyg.2019.01801.

[27] Quinn C, Nelis SM, Martyr A, Victor C, Morris RG, Clare L. Influence of Positive and Negative Dimensions of Dementia Caregiving on Caregiver Well-Being and Satisfaction With Life: Findings From the IDEAL Study. Regul Res Artic Am J Geriatr Psychiatry 2019;27:848. https://doi.org/10.1016/j.jagp.2019.02.005.

[28] Litzelman K, Tesauro G, Ferrer R. Internal resources among informal caregivers: trajectories and associations with well-being. Qual Life Res 2017;26:3239-50. https://doi.org/10.1007/s11136-017-1647-9.

[29] Fields NL, Xu L, Miller VJ. Caregiver Burden and Desire for Institutional Placement-The Roles of Positive Aspects of Caregiving and Religious Coping. Am J Alzheimer's Dis Other Dementias $® \quad$ 2019;34:199-207. https://doi.org/10.1177/1533317519826217.

[30] Xue H, Zhai J, He R, Zhou L, Liang R, Yu H. Moderating role of positive aspects of caregiving in the relationship between depression in persons with Alzheimer's disease and caregiver burden. Psychiatry Res 2018;261:400-5. https://doi.org/10.1016/j.psychres.2017.12.0 88.

[31] Smith KJ, George C, Ferreira N. Factors emerging from the "Zarit Burden Interview" and predictive variables in a UK sample of caregivers for people with dementia. Int Psychogeriatrics 2018;30:1671-8. https://doi.org/10.1017/S104161021800031 5.

[32] Hwang AS, Rosenberg L, Kontos P, Cameron JI, Mihailidis A, Nygård L. Sustaining care for a parent with dementia: an indefinite and intertwined process. Int J Qual Stud Health Well-Being 2017;12:1389578. https://doi.org/10.1080/17482631.2017.138 9578.

[33] Kuuppelomäki M, Sasaki A, Yamada K, Asakawa N, Shimanouchi S. Family carers for older relatives: Int J Nurs Stud 2004;41:497-505. https://doi.org/10.1016/j.ijnurstu.2003.11.00 4.

[34] Ekwall AK, Hallberg IR. The association between caregiving satisfaction, difficulties and coping among older family caregivers. J Clin Nurs 2007;16:832-44. https://doi.org/10.1111/j.13652702.2006.01382.x.

[35] Brodaty H, Donkin M. Family caregivers of people with dementia. Dialogues Clin Neurosci 2009;11:217-28. https://doi.org/10.1002/gps.2284.

[36] Sharma N, Chakrabarti S, Grover S. Gender differences in caregiving among family caregivers of people with mental illnesses. World J Psychiatry 2016;6:7. https://doi.org/10.5498/wjp.v6.i1.7.

[37] Alzheimer's Association. 2020 Alzheimer's disease facts and figures. Alzheimer's Dement 2020;16:391-460. https://doi.org/10.1002/alz.12068.

[38] Pinquart M, Sörensen S. Spouses, adult children, and children-in-law as caregivers of older adults: A meta-analytic comparison. Psychol Aging 2011;26:1-14. https://doi.org/10.1037/a0021863.

[39] Holahan CJ, Moos RH, Holahan CK, Brennan PL, Schutte KK. Stress Generation, Avoidance Coping, and Depressive Symptoms: A 10-Year Model. J Consult Clin Psychol 2005;73:658-66. https://doi.org/10.1037/0022-006X.73.4.658.

[40] Sequeira C. Difficulties, coping strategies, satisfaction and burden in informal Portuguese caregivers. J Clin Nurs 2013;22:491-500. https://doi.org/10.1111/jocn.12108.

[41] Schulz R, Eden J. Families caring for an aging America. 2016. https://doi.org/10.17226/23606. 